Volume 6 Nomor 2, Agustus 2021, halaman 207-221

\title{
DEVELOPMENT OF ETNOMATHEMATICS BASED FLAT BUILDING HANDOUTS FOR STUDENTS CLASS VII SMP
}

\section{PENGEMBANGAN HANDOUT BANGUN DATAR BERBASIS ETNOMATEMATIKA UNTUK SISWA KELAS VII SMP}

\author{
Endah Febriza ${ }^{1}$, Putri Yulia ${ }^{2 *}$, Selvia Erita ${ }^{3}$ \\ ${ }^{1,2,3}$ IAIN Kerinci, J1. Kapten Muradi, Kecamatan Sungai Liuk, Kota Sungai Penuh,Propinsi Jambi \\ 37112, Indonesia \\ Email: endahfebriza20@gmail.com, putriyuliamz@gmail.com*, selviaerita84@gmail.com
}

\begin{abstract}
ABSTRAK
Penelitian ini bertujuan untuk mengembangkan bahan ajar berupa handout bangun datar berbasis etnomatematika untuk siswa kelas VII SMP.Penelitian ini merupakan jenis Penelitian dan Pengembangan (research and development), proses pengembangan handout dengan menggunakan model 4D yaitu define, design, develop, disseminate. Penelitian ini dilakukan untuk mengetahui bagaimana tingkat kevalidan pada handout bangun datar berbasis etnomatematika untuk siswa kelas VII SMP.Berdasarkan hasil validasi oleh ahli materi di peroleh skor rata-rata sebesar $80 \%$ kriteria Valid. Hasil validasi oleh ahli media di peroleh skor rata-rata sebesar $84,61 \%$ dengan kriteria Sangat Valid. Hasil validasi oleh ahli bahasa di peroleh skor rata-rata sebesar $80 \%$ dengan kriteria Valid.Hal ini dapat di simpulkan bahwa bahan ajar yang dikembangkan mempunyai kriteria valid sehingga dapat digunakan sebagai bahan ajar dalam kegiatan belajar mengajar.
\end{abstract}

Kata Kunci: Handout, Etnomatematika

\section{ABSTRACT}

This study aims to develop teaching materials in the form of ethnomatics-based flat shape handouts for seventh grade students of SMP. This research is a type of Research and Development, the process of developing a handout using the 4D model, namely define, design, develop, disseminate. This study was conducted to determine the level of validity of ethnomatematics-based flat shape handouts for seventh grade students of SMP. Based on the results of the validation by material experts, an average score of $80 \%$ was obtained. Valid criteria. The results of the validation by media experts obtained an average score of $84.61 \%$ with very valid criteria. The results of the validation by linguists obtained an average score of $80 \%$ with valid criteria. It can be concluded that the teaching materials developed have valid criteria so that they can be used as teaching materials in teaching and learning activities.

Keywords: Handout, Ethnomatematic

How to Cite: Febriza, E., Yulia, P., \& Erita, S. (2021). Development Of Etnomathematics Based Flat Building Handouts for Students Class VII SMP. Mathline: Jurnal Matematika dan Pendidikan Matematika, Vol. 6 No. 2, 207-221.

DOI: https://doi.org/10.31943/mathline.v6i2.231 


\section{PRELIMINARY}

Mathematics has an important role to solve problems in everyday life and socio-cultural life as well as as a basis for logic or reasoning and solutions that can be used in other subjects (Bagindo \& Yulia, 2019). Learning mathematics is characterized by awareness of what is done, what is understood and what is not understood by students about mathematical facts, concepts and procedures. This conscious effort includes a conscious effort in achieving the goals of learning mathematics, one of which is to improve student learning outcomes (Masamah, 2018).

Mathematics learning aims to equip students with the ability to understand mathematical concepts, solve problems and have the nature of appreciating the usefulness of mathematics in everyday life, as well as shaping the mindset of students to be of high quality (Betyka et al., 2019) The achievement of learning objectives is the expectation of educators for students in the teaching and learning process, but implementing these goals is not an easy thing (Rosida et al., 2018). Whether or not the learning objectives have been achieved can be seen from the evaluation results after the learning process. In order for mathematics learning to be achieved in accordance with the competency standards required by students, including mastering the material, being able to use methods, teaching materials and other teaching aids needed in learning activities, and teachers must be able to explore and innovate in making learning elements that attract students. in the teaching and learning process (Cahyaningrum \& Sukestiyarno, 2016).

Based on information from interviews conducted with one of the mathematics teachers and students at State Junior High School 4 Sungai Penuh, learning mathematics in junior high schools generally uses textbooks. In addition, there are still many students who are not interested in learning mathematics, students think mathematics is difficult to understand, students have difficulty memorizing and using formulas, the teacher only gives questions in the textbook without explaining the material being studied, and students still take notes. the material in the LKS, as well as teaching materials that are incomplete, students want to have teaching materials that are more interesting and easy to understand.

Based on the existing problems, a teaching material was developed in the hope that it can help students understand the material and can help students obtain handbooks other than the existing textbooks. Teaching materials must have a form, content and way of presenting the material that attracts students to see, open and then read the teaching 
materials. The teaching materials developed are very important to support the academic achievement of students and can affect the quality of teaching during the learning carried out by the teacher. One of the teaching materials that can be used by educators in the learning process in class VII, especially at State Junior High School 4 Sungai Penuh, is to use handouts that prioritize the most important points in a material that is packaged briefly.

Teaching materials are all forms of materials used to assist in carrying out the learning process in the classroom (Santoso, Yulia, \& Rusliah, 2020). The use of teaching materials can make learning more meaningful (Rakhmawati, 2016). Teaching materials help students so that they are no longer fixated on the teacher's explanation (Rahmawati \& Marsigit, 2017). Students are free to explore their own knowledge, and then develop the knowledge they already have. The use of teaching materials during learning also creates a more active and communicative learning atmosphere and reduces teacher dominance during learning (Uyun, Holisin, \& Kristanti, 2017).

Associated with the many benefits of using teaching materials, it is very important for an educator to develop teaching materials that are innovative and in accordance with the needs of students. Teaching materials must have a unique and interesting form, content, and way of presenting the material. Unique and interesting teaching materials that can help students understand the concepts presented by the teacher so that learning objectives can be achieved optimally (Aini et al., 2018).

To achieve this goal, teaching materials are needed that can help students to discover and experience themselves firsthand, namely teaching materials in the form of handouts, because handouts can stimulate the curiosity of students in participating in learning (Rakhmawati, 2016). Handouts have an effect on completing the learning process and creating a more effective learning environment. Handouts can also increase students' curiosity about the material, so that students are encouraged to learn and keep learning (Rozalia et al., 2018).

Thus, the Handout was made with the aim of expediting and providing assistance with information or subject matter as a guide for students and also to increase students' knowledge. Educators can also provide direction about the relationship between students' daily knowledge and learning materials, and educators begin to use their knowledge to develop teaching materials needed by students. The limitations of educators in developing teaching or learning materials that have been launched should not be a reason for achieving a learning goal (Wahyuni, 2016). 
Handouts that can facilitate students to direct students' mindsets and build students' independence in learning are handouts based on ethnomathematics (Masamah, 2018). In ethnomathematics-based learning, the learning environment will turn into a pleasant environment for teachers and students, which allows teachers and students to actively participate based on the culture they already know, so that optimal learning outcomes can be obtained (Fajriyah, 2018).

Ethnomathematics is a study of the lifestyle, habits or customs of a society in a place that is related to mathematical concepts but is not based on mathematics by that society (Abi, 2016). Ethnomathematics is an approach that links mathematics with culture, this link is expected to be able to increase students' love of culture so that students can know the benefits of mathematics from a cultural perspective (Rusliah, 2016).

Ethnomathematics are certain ways used by a society or cultural group in mathematical activities (Mardiah et al., 2018). Mathematical activities involving culture that come from real experiences experienced in everyday life into mathematics such as grouping, counting, measuring, designing buildings or tools, making patterns, determining locations, games and so on (Dahlan \& Permatasari, 2018). Ethnomathematics can also be considered as a program that aims to study how students can understand, articulate, process and finally use mathematical ideas, concepts, practices that can solve problems related to their daily lives (Disnawati \& Nahak, 2019).

Thus, the ethnomathematics-based handouts developed will help students find new things, so that students will gain more knowledge. The activities in the handout facilitate students to always be active in finding the concepts being studied so that teachers can realize their role as facilitators in accordance with the demands of learning and involve students actively in the learning process (Munawaroh, 2011).

The purpose of the study was to find out how to develop and see the validity of the ethnomathematics-based flat handout for class VII SMP Negeri 4 Sungai Penuh. So that students can recognize the elements of mathematics that exist in their daily cultural environment in learning mathematics which is displayed in teaching materials in the form of handouts.

\section{METHOD}

The method used in this research is (research and development). Research and development (research and development) is a scientific way to research, design, produce, and test the validity of the products that have been produced (Sari et al., 2016). The 
research design used in this research and development uses the 4D development design developed by S. Thigharajan, Dorothy Semmel and Melvyn I. Semmel. The stages in this development are: Define, Design, Develop, Disseminate. The 4D flowchart is shown in Figure 1 below:

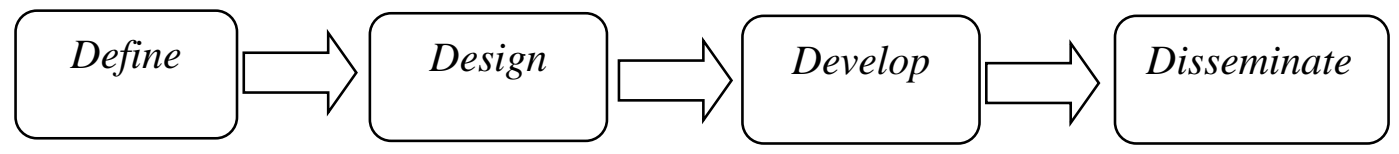

Figure 1. 4D Development Model

The definition stage, at this stage the steps of analyzing the mathematics lesson syllabus for class VII SMP are carried out to find out whether the material being taught is in accordance with the expected competencies. Analyzing handouts for math class VII SMP aims to see the contents of the handouts, presentation methods, practice questions and sample questions. Seeing the characteristics of students to make it easier to arrange teaching materials and the level of difficulty of the questions. Conduct discussions with teachers with the aim of knowing what problems are encountered in the learning process in class VII SMP.

In the design stage, at this stage, what is done is to design an ethnomathematicsbased flat shape handout. The next stage is the development stage. The purpose of this stage is to produce handout teaching materials. The activities carried out at this stage are the researchers validating the handout teaching materials to material experts and media experts, after that conducting a trial of student responses and teacher responses. The last stage, namely the dissemination stage (desiminate) is the final stage of development. The practicality of a product can be seen by calculating the student and teacher response questionnaire scores. The dissemination stage is carried out to promote the product to students so that it can be accepted by users, whether individuals, groups or systems (Yulia, 2009).

Table 1. Handout Validity Indicators

\begin{tabular}{cc}
\hline $\begin{array}{c}\text { Validity } \\
\text { Type }\end{array}$ & \multicolumn{1}{c}{ Indicators } \\
$\begin{array}{c}\text { Content } \\
\text { component } \\
\text { validity }\end{array}$ & 1. $\begin{array}{l}\text { The topics presented in the ethnomathematics-based } \\
\text { handout are in accordance with KI and KD, and the } \\
\text { indicators formulated. }\end{array}$ \\
\cline { 2 - 3 } & $\begin{array}{l}\text { 2. } \\
\text { The topics presented in the ethnomathematics-based } \\
\text { handout are in accordance with KI and KD, and the } \\
\text { indicators formulated. }\end{array}$ \\
3. $\begin{array}{l}\text { The description of the material and examples provided } \\
\text { are relevant and attract the attention of students. }\end{array}$ \\
\hline
\end{tabular}




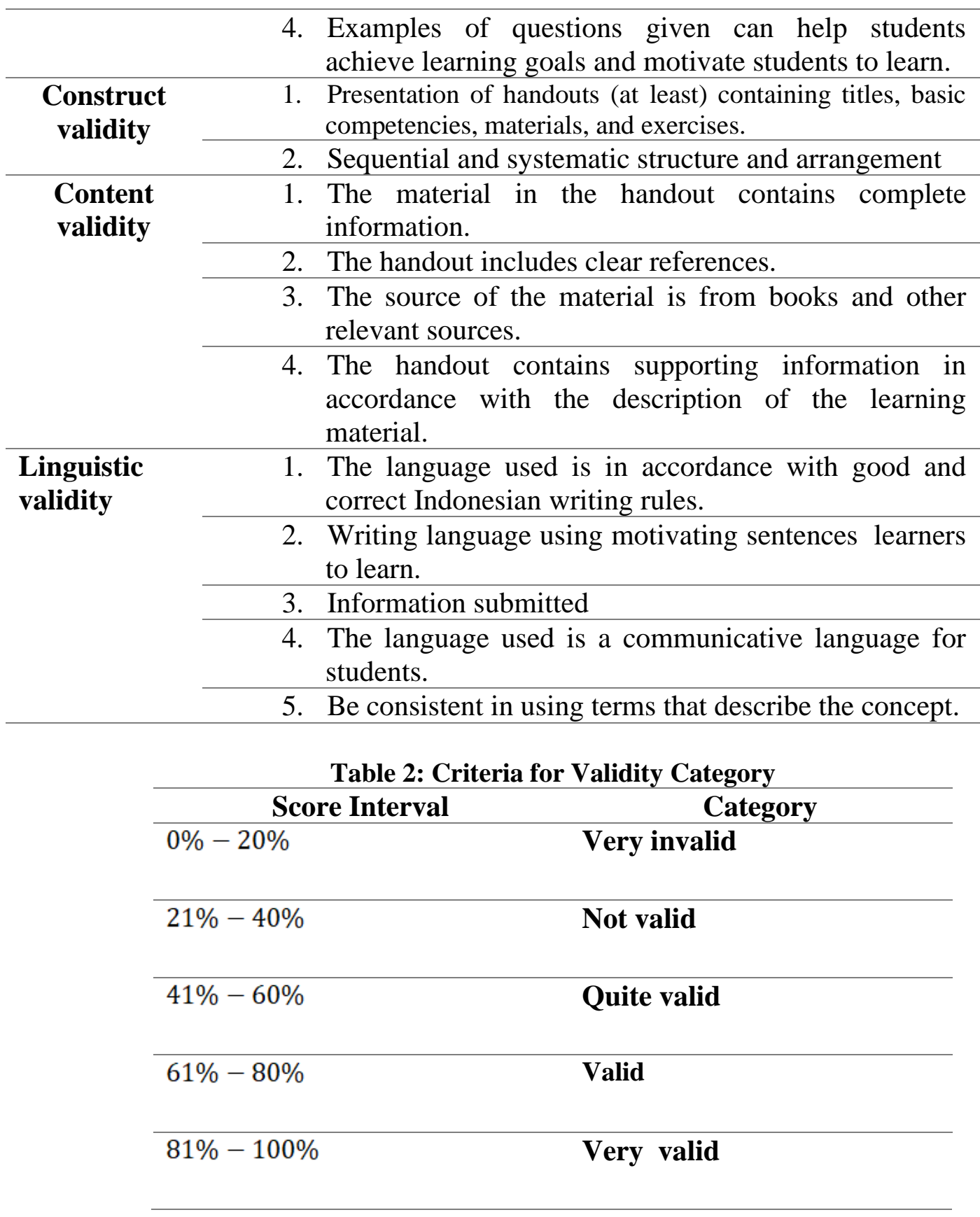

The criteria for the validity of the ethnomathematical-based flat shape handout are declared valid if the average reaches the predetermined criteria, namely $81 \%-100 \%$.

\section{RESULT AND DISCUSSION}

\section{Define stage}

The definition stage is the stage of analysis and problem identification to obtain various information related to products related to the product to be developed.

1. Front-end analysis 
Initial analysis is the process of identifying the problems faced when carrying out the learning process. This analysis is done by direct observation. The results of the observations show that there are still some problems faced in the teaching and learning process. This initial analysis is needed to determine whether these teaching materials need to be developed or not. Front-End Analysis (Front-End Analysis) is carried out in three steps, namely observation of learning activities, interviews with mathematics teachers and observations of the learning tools used.

Based on observations of mathematics learning activities at SMP Negeri 4 Sungai Penuh, it is known that many students still do not want to learn, especially for class VII junior high school students besides that students still have difficulty in finding mathematical calculation concepts, especially on flat-shaped material.

2. Concept analysis

In research conducted at SMP Negeri 4 Sungai Penuh, students are interested in culture-based learning. This is supported by the results of an interview with Mrs. Hasmaizar, S.Pd who is one of the mathematics teachers at SMP Negeri 4 Sungai Penuh. She stated that she had not yet developed a handout in ethnomathematics-based mathematics learning as teaching materials to support learning.

3. Task analysis

The task analysis is done by determining the materials based on the concept analysis. The results of this analysis are divided into several main materials, so that the material displayed in the handout teaching materials is arranged into several parts. In each subject matter, several tasks are given in order to master the handout teaching materials in depth.

4. Specifying instructional objectives

The formulation of learning objectives is the result of concept analysis and task analysis to determine the behavior of the research object. Before conducting a concept analysis, the researcher first conducts a front-end analysis.

\section{b. Design Stage}

After doing the definition stage, the next stage is the design stage. Several things were done in the product design stage of developing handout teaching materials based on ethnomathematics as follows:

1. Selection of Teaching Materials 
The selected teaching materials are ethnomathematics-based handouts which aim to facilitate the learning process, because ethnomathematics-based handouts have not been developed in SMP Negeri 4 Sungai Penuh.

2. Format selection

The selection of formats in learning development includes ethnomathematicalbased handout teaching materials that are made as attractive as possible and equipped with complementary components, images related to culture, accompanied by examples of questions and exercises. So that it can increase students' knowledge more broadly.

3. Initial design

The ethnomathematics-based handout teaching materials consist of a cover, a handout concept map, a table of contents, an introduction, and learning activities in the form of flat-shaped materials associated with ethnomathematics. The learning activities also contain examples of questions and exercises related to culture as well as bibliography taken from various sources.

\section{c. Develop Stage}

After carrying out the definition stage and the design stage, the researchers then made teaching materials in the form of ethnomathematical-based handouts. The steps taken at the development stage are:

1. Validation

Research and development of ethnomathematics-based handout teaching materials that have been designed, then validated at an early stage by validators who are given to material expert validators by Mrs. Rahmi Putri, M.Pd, media expert by Mr. Dr. Laswadi, M.Pd and a linguist by Mr. Dr. Nuzmi Sasferi, M.Pd. The results of expert validation are as follows:

a) Material Expert Validation.

Material validation aims to test the completeness of the material, the truth of the material and the systematics of the material. Because the results of material expert validation are $80 \%$, it is included in the valid category and deserves to be tested.

b) Media Expert Validation

Media expert validation aims to test the presentation of ethnomathematics-based handout teaching materials in mathematics learning. Media expert validation is carried out by lecturers from the Mathematics Tadris Department of IAIN Kerinci. The questionnaire used is 13 items of assessment with a score range of 1-5 points. Because 
the results of the media expert validation are $84.61 \%$, it is included in the valid category and deserves to be tested.

c) Linguist validation

The validation of linguists aims to find out the truth in using language in accordance with the EYD, writing and using sentences according to the EYD teaching materials for ethnomathematics-based flat-built handouts.

2. Product Revision

Revisions are made based on suggestions and inputs given by material experts, media experts, and linguists. As for the things that were revised in the ethnomathematicsbased handout teaching materials, among others, the material expert revised the clarity of the image that was still unclear, the image in the example still looked unclear and the image showed the part of the parallelogram on the rectangular elements.

Meanwhile, for the media expert, the revision was in the form of changing the cultural image on the cover, after being revised, the image on the cover had been corrected and replaced with a cultural image in Sungai Penuh. Replacing the mascot based on the existing culture in Sungai Penuh/Kerinci then the mascot has been repaired to become a mascot in the form of a traditional house related to local culture.

For Linguists, the revision is in the form of language clarity which is still unclear and the language on the handout has been corrected in accordance with linguistic rules. Furthermore, the use of the language of mathematical terms is still unclear and the use of language in mathematical terms has been improved and clarified

The product in the form of handouts for learning mathematics has specifications including handouts in the form of color print media in A4 paper size and using Times New Roman font size 12, spaced 1.5. The cover handout contains ethnomathematical elements in the form of the Kerinci woven pandanus motif and contains the identity of the handout. The cover handout based on ethnomathematics can be seen in the image below: 


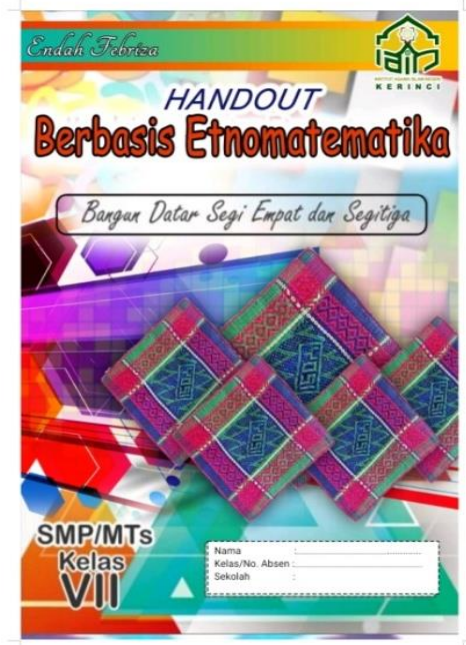

\section{Figure 2. Cover Handout Based On Ethnomathematics}

In addition, the content of the handout is associated with culture related to flat-shaped materials, one of which is woven pandanus. The handout presentation structure consists of three main components, including: an introduction which contains an introduction to the material in the handout, content and complements that enhance the handout components such as title page, table of contents, practice questions, summaries, evaluation questions, bibliography. An image of the contents of the ethnomathematics-based handout can be seen in the image below

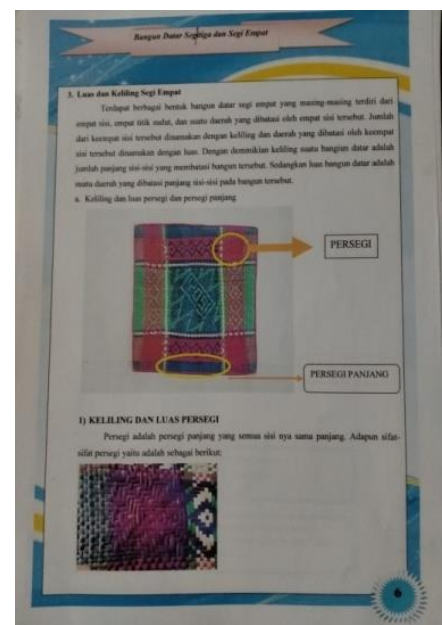

Figure 3. Contents Of Ethnomathematics-Based Handouts

3. Product Trial

After the product has gone through the validation stage by material experts, media experts, and linguists and the handout teaching materials have also been improved, then the product is tested with individual trials and small group trials consisting of 6 students. The results of product trials are as follows: 
a) Individual trial

Individual trials are carried out to ensure and determine the validity of teaching material products. This teacher trial amounted to 1 mathematics teacher at SMP Negeri 4 Sungai Penuh, class VII. After being tested, the researcher conducted interviews with the teacher concerned about the handouts that were developed. The results of the test on the teacher with suggestions for revision is to add sample questions and exercises so that students can deepen their understanding of the flat material that is associated with the culture around them.

Based on the results of interviews with mathematics teachers at SMP Negeri 4 Sungai Penuh, namely Mrs. Hasmaizar, S.Pd that she is interested in this ethnomathematics-based handout teaching material because she feels that the teaching materials applied at the time of the study are one of the new teaching materials used. in the process of learning mathematics. He also feels that using ethnomathematics-based handouts in the teaching and learning process can help and make it easier for students to understand the material because there are cultural elements in the students' environment. This teacher trial was also carried out to find out how the teacher understood the product, whether it was difficult for the handout teaching materials to be applied in learning.

b) Small group trial

In the small group trial phase, it was limited to small groups consisting of 6 students who had different abilities, namely students who had high ability, medium ability, and low ability students of SMP Negeri 4 Sungai Penuh. Small group trials were conducted by giving ethnomathematical-based handouts to students to understand and study, then students were interviewed one by one to find out input or suggestions regarding the ethnomathematical-based handout products that had been used by students.

After the teacher briefly explained the material for flat shapes to students, then students were given the opportunity to ask questions and do the exercises in the ethnomathematics-based flat shape handouts. The researcher paid attention to the students working on the questions and noted any obstacles while the students were working on the practice questions. For students who have high, medium and low abilities, it is not difficult and students easily understand the material in the ethnomathematics-based flat shape handout so that students can work on practice questions well, it can be seen in the answers of students with high, medium or low 
abilities. In the answers of students who have low abilities, there is still a small number of errors in working on the practice questions.

From the results of the interview, in general, students explained that they liked to learn mathematics by using ethnomathematics-based flat shape handout teaching materials and could foster students' curiosity about flat material that is easy to understand and explanations and examples of questions in the handout related to culture that are often they found.

Students said that learning by using this ethnomathematics-based flat shape handout made them familiar and aware of the relationship between mathematics and culture that they often find in their daily lives. The examples of questions and exercises in the ethnomathematics-based flat shape handouts make them know and care about the culture around them because they feel that they get a lot of new information about the culture of mathematics.

In the ethnomathematics-based handouts, students also like all the displays that are presented because they are in accordance with their wishes and there are no parts that make them confused when understanding and working on practice questions. So that the product can be used as a teaching material in teaching and learning activities in class VII flat building material at SMP Negeri 4 Sungai Penuh.

\section{d. The suitability of the Ethnomathematics-Based Flat Shape Handout with Development Goals}

The suitability of ethnomathematics-based flat shape handouts with development objectives. The purpose of this development is to develop an ethnomathematics-based mathematical flat shape handout in grade VII on the subject of flat shapes. The final product of this research is an ethnomathematics-based flat shape handout teaching material which contains experimental activities on flat shape material. The ethnomathematicalbased handouts are presented sequentially, namely handout covers, introduction, table of contents, introduction, contents of handouts, sample questions and exercises and bibliography. The display design used in the ethnomathematics-based flat shape handout has gone through the media test stage so that the results are said to be in accordance with the standards of learning teaching materials.

From the results of the media, material and linguistic tests, it can be concluded that the ethnomathematics-based flat shape handouts are appropriate and feasible to be applied as teaching materials that attract and motivate students to learn. This is in line with research (Indriani, 2018) which states that the application of ethnomathematical teaching 
materials can be a means to motivate, stimulate students, to overcome boredom and difficulties in learning mathematics. belonging to the local socio-cultural environment.

The criteria for the validity of the ethnomathematics-based flat shape handout on the aspect of the feasibility of the content can be said that the content of the ethnomathematical-based flat shape handout is appropriate and appropriate and fulfills the principles and provisions of the material in accordance with $\mathrm{KI}$ and $\mathrm{KD}$ and is sufficient in achieving the indicators of achievement of competencies that have been set. The criteria for the validity of the ethnomathematical-based flat shape handout on the linguistic aspects used are in accordance with good and correct Indonesian rules. In the aspect of displaying the validity criteria on the ethnomathematics-based flat shape handout, it has met the assessment aspects such as the selection of letters, layout, colors, images and the right size. This is in line with research (Tandililing, 2016) that assessed aspects in the manufacture of teaching materials in the form of media and language materials .

\section{CONCLUSION}

Based on the research results, it can be concluded that this development research uses a 4D stage model, namely defining, designing, developing, and disseminating. This development research has produced an ethnomathematics-based flat shape handout. At the definition stage, identification and problem analysis are carried out in the form of initial analysis, student analysis, concept analysis, task analysis and formulation of learning objectives. The results obtained from this definition stage found problems that required the development of an ethnomathematical-based flat shape handout. Ethnomathematics-based handouts were developed in the form of print media.

At the design stage, there are several steps, namely the preparation of a competency map, the formulation of the material, the selection of the handout format, and the writing of the module script. The development stage aims to produce finished products in the form of handouts that have been revised by material experts, language experts and media experts. Validation carried out by media experts and material experts was carried out to find out the shortcomings or weaknesses of the ethnomathematics-based flat shape handouts, product trials were carried out with individual trials carried out with experienced teachers in their fields, small group trials were carried out on 6 students who had different abilities, namely students with high, medium and low abilities. Based on the results of the analysis on the ethnomathematics-based flat shape handouts in this study, it has met the criteria for valid teaching materials and deserves to be tested. 
Based on the results of this study, suggestions are then proposed for teachers. Researchers suggest that ethnomathematical-based handouts can be developed and used as an alternative teaching material in overcoming students' learning difficulties and making it easier for teachers to deliver learning materials. For students, the researcher suggests that students take advantage of ethnomathematical-based handouts and can also increase students' insight and creativity. For other researchers who will continue this research, it is recommended to proceed to the practicality and effectiveness test stage on ethnomathematics-based flat shape handouts.

\section{REFERENCES}

Aini, E. P., Komarudin, \& Masykur, R. (2018). Handout Matematika berbantuan Etnomatematika Berbasis Budaya Lokal. Jurnal Matematika, 1(1), 73-79.

Auliya, N. N. F. (2015). Etnomatematika Kaligrafi Sebagai Sumber Belajar Matematika Di Madrasah Ibtidaiyah. Jurnal Pendidikan Matematika, 1(2), 76-98.

Bagindo, R., \& Yulia, P. (2019). Efektivitas Model Pembelajaran Aptitude Treatment Interaction (ATI) dengan Team Assisted Individualization (TAI) terhadap Hasil Belajar Siswa. PYTHAGORAS: Journal of the Mathematics Education Study Program, 8(1), 41-48.

Betyka, F., Putra, A., \& Erita, S. (2019). Pengembangan Lembar Aktivitas Siswa Berbasis Penemuan Terbimbing pada Materi Segitiga. JURING: Journal for Research in Mathematics Learning, 2(2), 179-189.

Cahyaningrum, N., \& Sukestiyarno, Y. (2016). Pembelajaran React Berbantuan Modul Etnomatematika Meningkatkan Kemampuan Pemecahan Masalah. Unnes Journal of Mathematics Education Research, 5(1), 50-59.

Dewi, E. K., \& Yulia, P. (2018). Efektivitas Penerapan Model Pembelajaran TAI dan PBI terhadap Hasil Belajar Matematika Siswa Kelas VIII SMPN 50 Batam. PYTHAGORAS: Journal of the Mathematics Education Study Program, 7(2), 4248.

Imswatama, A., Saprudin, \& Widyanto, R. (2018). Etnomatematika: Arsitektur Lumbung Padi "Leuit" Di Kawasan Geopark Ciletuh Sukabumi Sebagai Bahan Pembelajaran Matematika Di Sekolah Dasar. The Second Progressive and Fun Education Seminar, 2(1), 43-50.

Masamah, U. (2018). Pengembangan Pembelajaran Matematika Dengan Pendekatan Etnomatematika Berbasis Budaya Lokal Kudus. Jurnal Pendidikan Matematika, 1(2), 124-144.

Rahmawati, F. D., \& Marsigit. (2017). Pengembangan Bahan Ajar Berbasis Etnomatematika Ethnomathematics For Improve Achievement And Motivation To. Jurnal Pendidikan Matematika, 6(6), 69-76.

Rakhmawati, R. (2016). Aktivitas Matematika Berbasis Budaya pada Masyarakat Lampung. Al-Jabar: Jurnal Pendidikan Matematika, 7(2), 221-230, https://doi.org/10.24042/AJPM.V7I2.37.

Ratnasari, D., \& Yulia, P. (2018). Efektivitas model pembelajaran pbldan taiterhadap kemampuan pemecahan masalah matematis siswakelas vii smp negeri 47 batam. Pythagoras: Journal of the Mathematics Education Study Program, 7(1), 1-8.

Rosida, V., Taqwa, M., \& Kamaruddin, R. (2018). Efektivitas pendekatan etnomatika 
berbasis budaya lokal dalam pembelajaran matematika. Jurnal Pendidikan Matematika, 2(2), 97-107.

Rozalia, A., Kasriana, \& Irwandi, A. (2018). Pengembangan handout biologi materi keanekaragaman hayati untuk sma kelas x. Jurnal Pendidikan Dan Pembelajaran Biologi, 2(2), 44-51.

Santoso, G., Yulia, P., \& Rusliah, N. (2020). Validitas Lembar Kerja Peserta Didik (LKPD) Berbasis Etnomatematika pada Materi Geometri dan Pengukuran. PYTHAGORAS: Journal of the Mathematics Education Study Program, 9(2), 165172.

Sari, fiska komala, Farida, \& Syazali, M. (2016). pengembangan Media Pembelajaran (Modul) Berbantuan Geogebra Pokok Bahasan Turuna. Jurnal Pendidikan Matematika, 7(2), 135-152.

Uyun, Q., Holisin, I., \& Kristanti, F. (2017). Pengembangan Media Handout Segitiga Dengan Model Problem Based Instruction Program Studi Pendidikan Matematika. MUST: Journal of mathematics education, science and technologhy, 2(1), 115-128.

Wahyuni, I. (2016). Eksplorasi Etnomatematika Masyarakat Pesisir. Fenomena, 15(2), 225-238.

Yulia, P. (2016). Pengembangan Perangkat Pembelajaran Berbasis Problem Based Learning (PBL) untuk Kelas V SD. Jurnal Seminar Nasional, 1(1), 172-179.

Yulia, P. (2016). Efektifitas Model Pembelajaran CTL (Contextual Teaching And Learning) Terhadap Kemampuan Pemecahan Masalah Matematis Siswa Kelas VIII SMP N 16 Batam Tahun Pelajaran 2014/2015. Pythagoras: Journal of the Mathematics Education Study Program, 5(1), 52-58. 